University of Nebraska - Lincoln

DigitalCommons@University of Nebraska - Lincoln

\title{
Pesticide And Transformation Product Detections And Age-Dating Relations From Till And Sand Deposits
}

Kelly L. Warner

U.S. Geological Survey, klwarner@usgs.gov

William S. Morrow

U.S. Geological Survey

Follow this and additional works at: https://digitalcommons.unl.edu/usgsstaffpub

Warner, Kelly L. and Morrow, William S., "Pesticide And Transformation Product Detections And AgeDating Relations From Till And Sand Deposits" (2007). USGS Staff -- Published Research. 614.

https://digitalcommons.unl.edu/usgsstaffpub/614

This Article is brought to you for free and open access by the US Geological Survey at DigitalCommons@University of Nebraska - Lincoln. It has been accepted for inclusion in USGS Staff -- Published Research by an authorized administrator of DigitalCommons@University of Nebraska - Lincoln. 


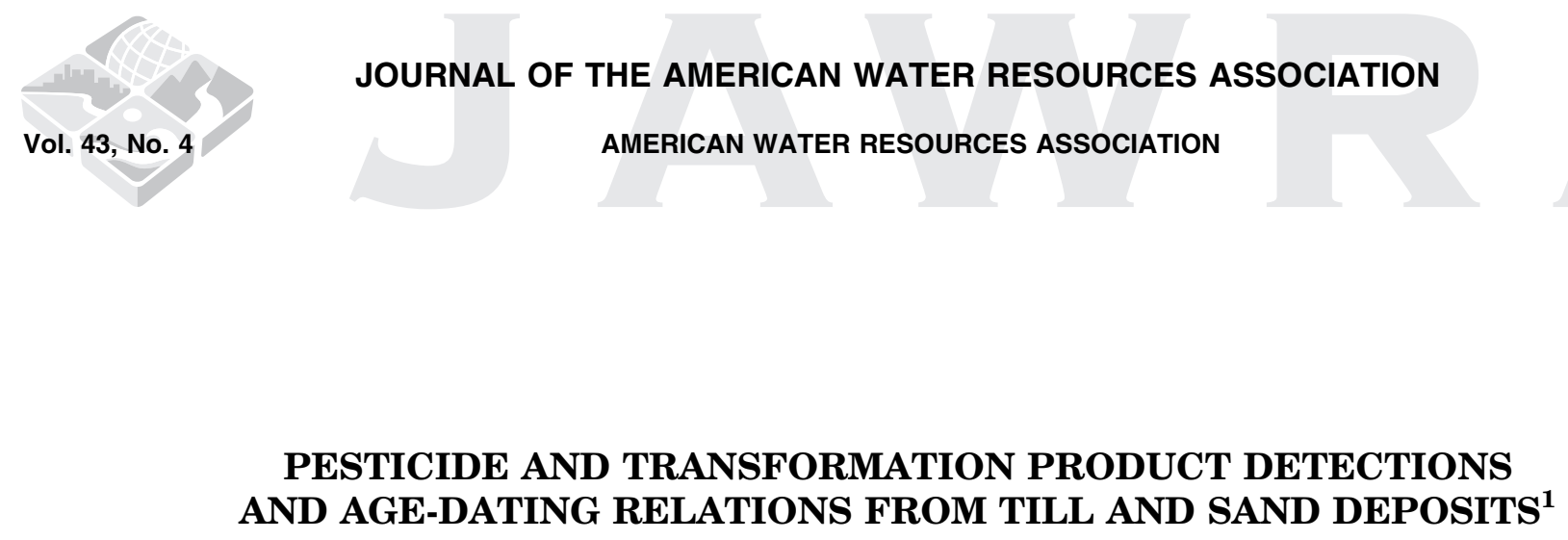

\author{
Kelly L. Warner and William S. Morrow ${ }^{2}$
}

\begin{abstract}
Pesticide and transformation product concentrations and frequencies in ground water from areas of similar crop and pesticide applications may vary substantially with differing lithologies. Pesticide analysis data for atrazine, metolachlor, alachlor, acetochlor, and cyanazine and their pesticide transformation products were collected at 69 monitoring wells in Illinois and northern Indiana to document occurrence of pesticides and their transformation products in two agricultural areas of differing lithologies, till, and sand. The till is primarily tile drained and has preferential fractured flow, whereas the sand primarily has surface water drainage and primary porosity flow. Transformation products represent most of the agricultural pesticides in ground water regardless of aquifer material - till or sand. Transformation products were detected more frequently than parent pesticides in both the till and sand, with metolachlor ethane sulfonic acid being most frequently detected. Estimated ground-water recharge dates for the sand were based on chlorofluorocarbon analyses. These age-dating data indicate that ground water recharged prior to 1990 is more likely to have a detection of a pesticide or pesticide transformation product. Detections were twice as frequent in ground water recharged prior to 1990 (82\%) than in ground water recharged on or after 1990 (33\%). The highest concentrations of atrazine, alachlor, metolachlor, and their transformation products, also were detected in samples from ground water recharged prior to 1990. These age/pesticide detection relations are opposite of what would normally be expected, and may be the result of preferential flow and/or ground-water mixing between aquifers and aquitards as evident by the detection of acetochlor transformation products in samples with estimated ground-water ages predating initial pesticide application.
\end{abstract}

(KEY TERMS: pesticides; ground water hydrology; recharge; transformation product; age dating; glacial deposits.)

Warner, Kelly L., and William S. Morrow, 2007. Pesticide and Transformation Product Detections and AgeDating Relations from Till and Sand Deposits. Journal of the American Water Resources Association (JAWRA) 43(4):911-922. DOI: $10.1111 / \mathrm{j} .1752-1688.2007 .00067 . x$

\section{INTRODUCTION}

The generally greater occurrence and frequency of pesticide transformation products in relation to their original pesticides have been documented in ground water in various areas underlying the Midwest (Kolpin et al., 1994, 1996b, 2000; Barbash et al., 1999; Kolpin et al., 2000; Savoca et al., 2000; Bayless, 2001; Morrow, 2003). It is not known, however, how

\footnotetext{
${ }^{1}$ Paper No. J05060 of the Journal of the American Water Resources Association (JAWRA). Received May 3, 2005; accepted October 26, 2006. (๑) 2007 American Water Resources Association. No claim to original U.S. government works. Discussions are open until February 1, 2008.

${ }^{2}$ Respectively (Warner and Morrow), U.S. Geological Survey, Water Resources Division, Illinois District, 221 N. Broadway, Urbana, Illinois 61801 (E-Mail/Warner: klwarner@usgs.gov).
} 
pesticide and transformation product concentrations and frequencies in ground water from areas of similar crop and pesticide applications vary with differing lithologies and associated aquifer properties and drainage characteristics. Although a large number of studies have documented extensive pesticide contamination of ground water in highly permeable aquifers in Wisconsin, Nebraska, Illinois, New York, and California, these studies generally did not sample ground water in nearby, less permeable areas for comparison (Barbash and Resek, 1996). Additionally, published research on pesticide and transformation products in ground water in Illinois and Indiana is currently limited, especially in thick glacial till.

Previous studies on pesticides in ground water in Illinois and surrounding area have shown low detection frequencies even though the use of pesticides is extensive. Results from pesticide studies in the early 1990 's found the presence of at least one pesticide in $12 \%$ of private wells sampled in Illinois (Ray and Schock, 1996), whereas $8 \%$ of sites sampled (92\% drinking-water supply wells) in Indiana had a detection of at least one pesticide (Risch, 1993). Preliminary results from the Cooperative Private Well Testing Program (Baker et al., 1994) show a lower frequency of triazine herbicide occurrence (at concentrations above $3 \mu \mathrm{g} / \mathrm{l}$ ) in Illinois than in Indiana and Ohio, two other high pesticide-use States in the mid-continent (Barbash and Resek, 1996). Subsequent research on drinking water in Ohio, Illinois, and Iowa found population-weighted average atrazine exposure from drinking ground water to be similar in Illinois and Ohio, but more than twice as high in Iowa (Richards et al., 1995).

Many pesticides form transformation products in the subsurface, either with, or without, microbial involvement. The rates and pathways of these reactions are affected by a variety of physical, chemical, and biological factors. Transformation reactions also are affected by the presence and characteristics of the resident Earth materials, the nature of these effects being dependent, in turn, on the chemical structure of the pesticide of interest (Barbash and Resek, 1996). Pesticide transformation products formed through transformation reactions have been detected in high concentrations and greater frequency than original pesticides in Iowa (Kolpin et al., 2000). For example, atrazine rapidly transforms through first-order kinetics (Wagenet et al., 2000), and its transformation products often are detected more frequently than atrazine in ground water. The possible higher concentrations and frequency are important because it is possible for pesticide transformation products to retain the herbicidal activity and toxicity of the original pesticides, as well as the comparable harmful physiological effects of some pesticides (Kolpin et al., 1998). The U.S.
Environmental Protection Agency (USEPA) considers transformation products in the environment important enough to include selected triazine transformation products on the drinking-water contaminant candidate list as a priority; and acetochlor ethane sulfonic acid (ESA) and alachlor ESA in drinking water as needing more research (USEPA, 1998, 2005).

The results presented here are part of the National Water-Quality Assessment (NAWQA) program of the U.S. Geological Survey (USGS) to assess the water quality of the Nation. This study in Illinois and northern Indiana compares pesticide and pesticide transformation product analyses from near-surface (less than $18 \mathrm{~m}$ from land surface) ground water from two deposits with similar overlying agricultural land use of corn and beans, with similar pesticide applications, but with different lithologies-till and sand. The till is primarily tile drained and has preferential fractured flow through till fracturing and macropores, whereas the sand is not tile drained (but does have surface water ditch drainage) and primary porosity flow through the sand. The pesticides analyzed in this study are atrazine, metolachlor, acetochlor, cyanazine, and alachlor; all these pesticides are used to control broad leaf and grassy weeds in corn, with some occasional use on soybeans. These pesticides have different half-lifes, water solubility, and sorption coefficients (Table 1) which affect the fate and mobility of each pesticide. Samples for common transformation products of these pesticides also were analyzed (Table 2). For the purpose of this paper, the till refers to the uppermost water-bearing unit in till, whereas the sand refers to the uppermost water-bearing unit in glaciofluvial sand.

\section{MATERIALS AND METHODS}

The two study areas consist of shallow monitoring well sets installed in Illinois and Indiana as part of the USGS NAWQA program to study agricultural land-use effects (Figure 1). Agriculture is the primary land use in these two study areas. Illinois and Indiana have the fifth and tenth, respectively, highest crop application of combined pesticides in the country, in kg applied per year (Gianessi and Marcelli, 2000).

The monitoring wells in the till and sand were selected and installed in agricultural land-use recharge areas according to USGS and NAWQA guidelines (Figure 1) (Scott, 1990; Lapham et al., 1995). The till and sand areas are both generally flat, and dominantly agricultural with corn and beans being the major crops. Most soils are mollisols, dark-colored soils with 
TABLE 1. Pesticide Movement Ratings, Soil Half-Lifes, Water Solubility, and Sorption Coefficients for Pesticides Analyzed (from Wauchope et al., 1992; Monsanto Company, 2003).

\begin{tabular}{llccr}
\hline Pesticide Name & $\begin{array}{c}\text { Pesticide Movement } \\
\text { Rating }\end{array}$ & $\begin{array}{c}\text { Soil Half-Life } \\
\text { (days) }\end{array}$ & $\begin{array}{c}\text { Water Solubility } \\
(\mathbf{m g} / \mathbf{L})\end{array}$ \\
\hline Acetochlor & & $3.4-29$ & 223 & $74-422$ \\
Alachlor & Moderate & 15 & 240 & 170 \\
Atrazine & High & 60 & 33 & 100 \\
Cyanazine & Low & 14 & 170 & 190 \\
Metolachlor & High & 90 & 530 & 200 \\
\hline
\end{tabular}

TABLE 2. Pesticides and Pesticide Transformation Products Analyzed.

Chemical Name

Acetochlor

Acetochlor ethane sulfonic acid (acetochlor ESA)

Acetochlor oxanilic acid (acetochlor OA)

Alachlor

Alachlor ethane sulfonic acid (alachlor ESA)

Alachlor oxanilic acid (alachlor OA)

Atrazine

Deethylatrazine

Deisopropylatrazine

Hydroxyatrazine

Cyanazine

Cyanazine-amide

Metolachlor

Metolachlor ethane sulfonic acid (metolachlor ESA)

Metolachlor oxanilic acid (metolachlor OA) 2-chloro- $N$-(ethoxymethyl)- $N$-(2-ethyl-6-methylphenyl)acetamide

2-[(2-ethyl-6-methylphenyl)(ethoxymethyl)amino]-2-oxoethane sulfonic acid

2-[(2-ethyl-6-methylphenyl)(ethoxymethyl)amino]-2-oxoacetic acid

2 -chloro-2'-6'-diethyl- $N$-(methoxymethyl)-acetamide

2 -[(2,6-diethylphenyl)(methoxymethyl)amino]-2-oxoethane sulfonic acid

2-[(2,6-diethylphenyl)(methoxymethyl)amino]-2-oxoacetic acid

2-chloro-4-ethylamino-6-isopropylamino-s-triazine

2-amino-4-chloro-6-(isopropylamino)-s-triazine

2-amino-4-chloro-6-(ethylamino)-s-triazine

2-hydroxy-4-(ethylamino)-6-(isopropylamino)-s-triazine

2-[[4-chloro-6-(ethylamino)-1,3,5-triazin-2-yl]amino]-2-methyl propionitrile

2-chloro-4-(1-carbamoyl-1-methyl-ethylamino)-6-ethylamino-s-triazine

2-chloro- $N$-(2-ethyl-6-methylphenyl)- $N$-(2-methoxy-1-methylethyl)acetamide

2-[(2-ethyl-6-methylphenyl)(2-methoxy-1-methylethyl)amino]-2-oxoethane sulfonic acid 2-[(2-ethyl-6-methylphenyl)(2-methoxy-1-methylethyl)amino]-2-oxoacetic acid

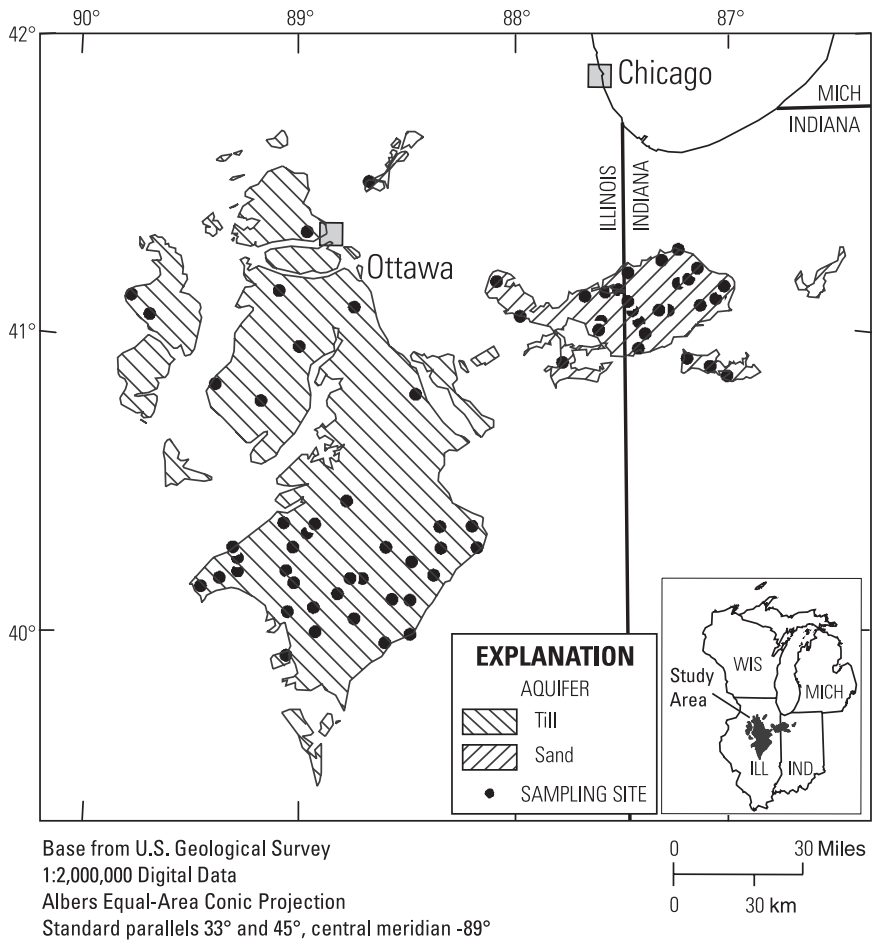

FIGURE 1. Location of Ground-Water Sampling Sites Within the Study Area. more than $1 \%$ organic matter, with the sand areas also having entisols - sandy, light colored soils (Arnold et al., 1999; Warner, 1998).

The till study area is in central Illinois (Figure 1). The area deposits consist of glacial till of the Wisconsinan Bloomington Ridged Plain, primarily the Wedron Formation, which is mostly till with intercalated gravel, sand, and silt lenses (Willman et al., 1975). Tile drains in cropland discharging to ditches and streams are common (and has increased since the $1970 \mathrm{~s}$ with the introduction of plastic tile) because of the low permeability of the clayey glacial deposits. Irrigation is not common in the area, usually only occurring when required for seed corn contracts. The 40 monitoring wells were sampled for pesticides and pesticide transformation products from July through October in 1997. The well depths ranged from 4 to $17.9 \mathrm{~m}$ with a median depth of $6.9 \mathrm{~m}$. The material surrounding the $1.5 \mathrm{~m}$ screened interval is fine-grained and clayey with discontinuous fine to coarse sand layers usually less than $15 \mathrm{~cm}$ thick. The median thickness of confining units (clay, clayey silt, till) is $5.0 \mathrm{~m}$ and the median thickness of the producing units (sand, silt, and sandy loess) is $1.5 \mathrm{~m}$ based on lithology from land surface to bottom of screen. 
The sand study area is in northeastern Illinois and northwestern Indiana (Figure 1). The area deposits consist mainly of fine- to medium-grained sands with intermittent clayey silt of the Wisconsinan Kankakee Till Plain/Kankakee Outwash and Lacustrine Plain. The deposits are primarily the Henry Formation, consisting of glacial outwash sands and gravels, and the Parkland Sand (in Illinois)/Atherton Formation (in Indiana) which consists of windblown sand (Willman et al., 1975) with exposed sand at the surface fairly common. Because near-surface sands that are present provide natural drainage, tile-drain systems are not common. Surface-water drainage ditches adjacent to the sandy cropland are the most common drainage feature. The area overlying the sand can be irrigated heavily locally. The 29 monitoring wells were sampled for pesticides and transformation products from June through September in 1999. The well depths ranged from 3.4 to $15.2 \mathrm{~m}$ with a median depth of $4.2 \mathrm{~m}$. The material surrounding the screened interval $(1.5 \mathrm{~m})$ of the wells is mostly sand. The approximate median thickness of confining units (clay, clayey silt, till) is $0.6 \mathrm{~m}$ and the median thickness of the producing units (sand, silt, sandy loess) is $4.0 \mathrm{~m}$ based on the lithology from land surface to the bottom of screen.

Sampling sites were selected in areas of similar pesticide application rates. Average individual pesticide application rates over each entire study area were calculated by multiplying the average cropland pesticide application rate for Illinois or Indiana for the year of sampling by the percentage of cropland planted per county. This value then was multiplied by the percentage of cropland that was treated with the pesticide, based on data from the U.S. Department of Agriculture (USDA, 1997, 1999). This procedure results in an application rate of the pesticide in relation to the entire study area, not just the cropland, and gives a better general view of relative use of each pesticide in the study area. Estimated applications indicate that pesticides were applied over the till and sand in Illinois and Indiana at about the same level, in $\mathrm{kg} / \mathrm{ha}$, in both aquifers (Table 3).

Hydraulic conductivities were determined from slug tests of 30 of 40 wells in the till, and 26 of 29 wells in the sand. All hydraulic conductivity values were calculated using the Bouwer and Rice (1976), and Cooper et al. (1967) methods. The median sand hydraulic conductivity was $4.0 \mathrm{~m} /$ day. The 10 wells without slug tests were determined to recharge too slowly to perform slug tests with the field time available, based on sampling and developing observations. If it is assumed that the 10 wells not tested were lower than the lowest slug-test conductivity value, then the median conductivity for the till is $0.2 \mathrm{~m} /$ day. Physical and chemical parameter data were collected for all wells and are listed in Table 4.

Pesticides and transformation products were collected at the 69 wells (40 in the till, and 29 in the sand) using NAWQA "ultra-clean" sample-collection methods (Koterba et al., 1995). Pesticides analyzed were acetochlor, alachlor, atrazine, cyanazine, and metolachlor. Pesticide transformation products analyzed were acetochlor ESA, acetochlor oxanilic acid (OA), alachlor ESA, alachlor OA, cyanazine-amide,

TABLE 3. Pesticides Detections and Pesticide Application Rates for the Till and Sand [Pesticide Application Estimates Calculated from State Pesticide Applications and County Crop Areas (U.S. Department of Agriculture, 1997; U.S. Department of Agriculture, 1999)].

\begin{tabular}{|c|c|c|c|c|c|c|c|}
\hline \multirow[b]{2}{*}{$\begin{array}{l}\text { Pesticide and Related } \\
\text { Transformation Products }\end{array}$} & \multirow[b]{2}{*}{$\begin{array}{c}\text { Method } \\
\text { Reporting } \\
\text { Level } \mu \mathrm{g} / 1\end{array}$} & \multicolumn{3}{|c|}{ Till } & \multicolumn{3}{|c|}{ Sand } \\
\hline & & $\begin{array}{c}\text { Pesticide } \\
\text { Application } \\
\text { Rate kg/ha }\end{array}$ & $\begin{array}{c}\text { Detection } \\
\text { Frequency } \\
(40 \text { samples) } \%\end{array}$ & $\begin{array}{c}\text { Range of } \\
\text { Concentrations } \\
\mu \mathrm{g} / 1\end{array}$ & $\begin{array}{c}\text { Pesticide } \\
\text { Application } \\
\text { Rate kg/ha }\end{array}$ & $\begin{array}{c}\text { Detection } \\
\text { Frequency } \\
(29 \text { samples }) \%\end{array}$ & $\begin{array}{c}\text { Range of } \\
\text { Concentrations } \\
\mu \mathrm{g} / 1\end{array}$ \\
\hline Acetochlor & 0.05 & 0.28 & 0 & $<0.05$ & 0.22 & 0 & $<0.05$ \\
\hline $\begin{array}{l}\text { Acetochlor ethane } \\
\text { sulfonic acid (ESA) }\end{array}$ & 0.2 & $\begin{array}{l}\text { not applicable } \\
\text { (na) }\end{array}$ & 0 & $<0.2$ & na & 24 & $<0.20-1.87$ \\
\hline Acetochlor oxanilic acid (OA) & 0.2 & na & 8 & $<0.20-0.65$ & na & 3 & $<0.20-1.01$ \\
\hline Alachlor & 0.05 & 0.01 & 0 & $<0.05$ & 0.02 & 3 & $<0.05-0.92$ \\
\hline Alachlor ESA & 0.2 & na & 3 & $<0.20-0.60$ & na & 24 & $<0.20-3.06$ \\
\hline Alachlor OA & 0.2 & na & 0 & $<0.2$ & na & 3 & $<0.20-3.06$ \\
\hline Atrazine & 0.05 & 0.44 & 5 & $<0.05-0.12$ & 0.46 & 10 & $<0.05-0.41$ \\
\hline Deethylatrazine & 0.05 & na & 5 & $<0.05-0.11$ & na & 7 & $<0.05-0.83$ \\
\hline Deisopropylatrazine & 0.05 & na & 3 & $<0.05-0.14$ & na & 7 & $<0.05-0.21$ \\
\hline Hydroxyatrazine & 0.2 & na & 8 & $<0.20-1.14$ & na & 0 & $<0.20$ \\
\hline Cyanazine & 0.05 & 0.16 & 0 & $<0.05$ & 0.13 & 0 & $<0.05$ \\
\hline Cyanazine-amide & 0.05 & na & 0 & $<0.05$ & na & 0 & $<0.05$ \\
\hline Metolachlor & 0.05 & 0.36 & 5 & $<0.05-0.40$ & 0.39 & 3 & $<0.05-0.53$ \\
\hline Metolachlor ESA & 0.2 & na & 25 & $<0.20-33.9$ & na & 31 & $<0.20-9.08$ \\
\hline Metolachlor OA & 0.2 & na & 10 & $<0.20-11.5$ & na & 14 & $<0.20-4.49$ \\
\hline
\end{tabular}


TABLE 4. Chemical and Physical Parameters of Wells in the Till and Sand.

\begin{tabular}{|c|c|c|c|c|c|c|c|}
\hline \multirow[b]{2}{*}{ Parameter } & \multirow[b]{2}{*}{ Units } & \multicolumn{3}{|c|}{ Till } & \multicolumn{3}{|c|}{ Sand } \\
\hline & & Minimum & Maximum & Median & Minimum & Maximum & Median \\
\hline Specific conductance & $\mu \mathrm{S} / \mathrm{cm}$ & 214 & 1840 & 740 & 119 & 1020 & 391 \\
\hline $\mathrm{PH}$ & Standard units & 6.6 & 8 & 7 & 5.9 & 8.4 & 7.2 \\
\hline Dissolved oxygen & $\mathrm{mg} / 1$ & 0.1 & 7.4 & 2.3 & 0.1 & 7.5 & 2.9 \\
\hline Alkalinity (as $\mathrm{mg} \mathrm{L}^{-1}$ of calcium carbonate) & $\mathrm{mg} / \mathrm{l}$ & 220 & 636 & 370 & 17 & 342 & 142 \\
\hline Water temperature & ${ }^{\circ} \mathrm{C}$ & 11 & 26.5 & 16 & 11.5 & 34 & 19.5 \\
\hline Well depth & $\mathrm{m}$ & 4.0 & 17.9 & 6.9 & 3.4 & 15.2 & 4.2 \\
\hline Water level below land surface & $\mathrm{m}$ & 0.10 & 14.1 & 3.0 & 0.76 & 10.8 & 2.1 \\
\hline Hydraulic Conductivity & $\mathrm{m} /$ day & $<0.009$ & 166 & 0.2 & 0.003 & 22 & 4.0 \\
\hline
\end{tabular}

deethylatrazine, deisopropylatrazine, hydroxyatrazine, metolachlor ESA, and metolachlor OA. Samples were analyzed by the USGS Organic Geochemistry Research Laboratory in Lawrence, Kansas. Field and laboratory quality assurance samples consisting of blanks, spikes, and replicates were collected to verify sampling and analytical procedures (Zimmerman and Thurman, 1999; Kish et al., 2000; Zimmerman et al., 2000).

Ground-water recharge date estimates were obtained for both the till and sand. In the till, recharge dates were estimated using tritium-dating methods (Thatcher et al., 1977), whereas in the sand, recharge dates were estimated using chlorofluorocarbon (CFC)-dating methods (Plummer and Busenberg, 1999; Plummer and Friedman, 1999). The tritiumdating method is less precise than the CFC-dating method, but was used because of anticipated low dissolved oxygen concentrations, and availability and cost of equipment. Tritium concentrations were used in this report only as a general indicator of recharge age because of the difficulty in establishing a definitive tritium concentration/age relation from tritium in precipitation data. Water samples with tritium concentrations were estimated to be either before or after 1952 (the beginning of above-ground nuclear device testing), with samples below the reporting level of 1.8 tritium units (TUs) assumed to be recharged prior to 1952, whereas water samples with tritium concentrations higher than $1.8 \mathrm{TU}$ are considered to have, at least some, post-1952 recharge.

Method reporting levels varied. All parent pesticides and the triazine transformation products, except for hydroxyatrazine, had a method reporting level of $0.05 \mu \mathrm{g} / \mathrm{l}$. Hydroxyatrazine and the acetamide pesticide (acetochlor, alachlor, and metolachlor) transformation products had a method reporting level of $0.20 \mu \mathrm{g} / \mathrm{l}$. A substantial amount of data would be rejected if the censoring level is raised to $0.20 \mu \mathrm{g} / \mathrm{l}$; therefore, the uncensored data were used when comparing detection frequencies. The net effect of these different reporting levels is underestimation of hydroxyatrazine and the acetamide transformation products in relation to the parent compounds and triazine compounds, because a lower reporting level would probably increase the detection frequency of the acetamide and hydroxyatrazine transformation products. Because concentrations and detection frequencies of acetamide transformation products (and hydroxyatrazine in the till) generally were higher than the parent products and triazine transformation products, the general trends and patterns would not change, and probably would strengthen if reporting levels were similar.

\section{RESULTS AND DISCUSSION}

Although no pesticide or pesticide transformation product concentrations exceeded USEPA drinkingwater standards or health-based screening levels (Toccalino et al., 2004), over half of the pesticide compounds considered in this investigation did not have a drinking-water standard.

\section{Total Pesticide Concentrations}

The total pesticide concentrations (the sum of analyzed pesticide and transformation product concentrations in ground water) were examined because of the low individual pesticide detection frequency and because studies have shown that some combinations of pesticides may have additive or synergistic toxic effects (Kolpin et al., 1998). Total pesticide concentrations were less frequently detected in the till $(35 \%)$ than the sand (55\%). The frequency of detection for individual pesticides and transformation products also are lower in the till compared to the sand (Figure 2). This may be the result of agricultural drainage practices, pesticide and clay interaction, or 


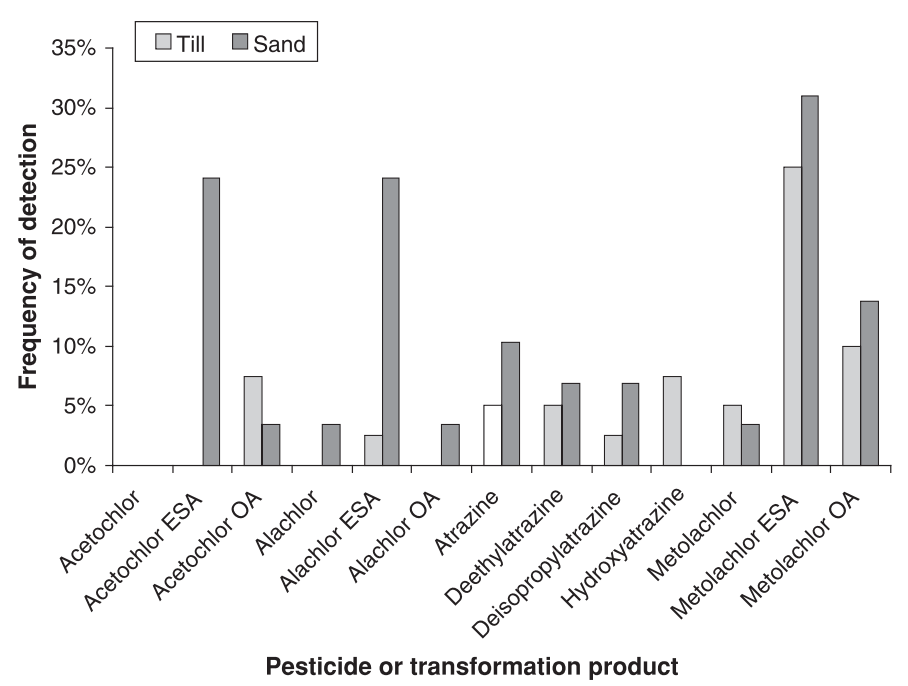

FIGURE 2. Detection Frequency for Pesticides and Transformation Products in the Till and Sand.

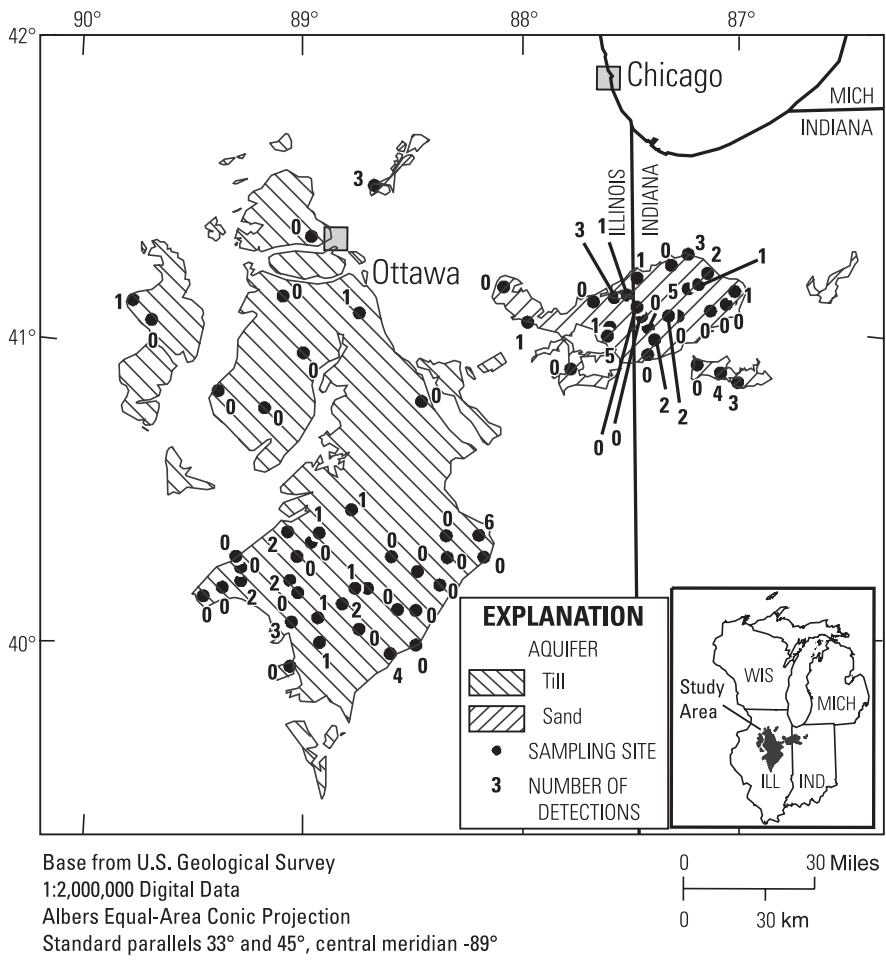

FIGURE 3. Number of Pesticide or Transformation Product Detections per Ground-Water Sample in the Till and Sand.

combination of both. The average number of detections per well was 0.7 for the till, and 1.3 detections per well for the sand. The number of pesticide detections per well is shown in Figure 3. The maximum total pesticide concentration in one well sample was $46.9 \mu \mathrm{g} / 1$ in the till, and $17.3 \mu \mathrm{g} / \mathrm{l}$ in the sand. Pesticide, transformation product, and total concentrations for both aquifers are shown in Figure 4 and Figure 5 . Well locations and number of pesticides or transformation product detections are shown in Figure 3. Total pesticide concentrations did not correlate with well depth or water level, with Spearman Rank correlations of less than -0.30 for all correlations. This lack of correlation may be affected by combining individual pesticides having different soil sorption, solubility, and reducing/oxidizing properties. The median concentration of total pesticides in samples from the sand is $0.20 \mu \mathrm{g} / \mathrm{l}$; the median concentration for samples from the till is less than the method reporting levels $(0.05-0.20 \mu \mathrm{g} / \mathrm{l})$. There is a statistical difference in total pesticide concentration between the till and sand using the non-parametric Kruskal-Wallis test $(p \leq 0.05)$ (Helsel and Hirsch, 1992). Lower concentrations of pesticides and nitrate in low-permeability agricultural areas of high pesticide and nitrate application have been suggested to be the result of the low permeability soil and underlying deposits and resulting increased tile drainage (Mueller et al., 1995; Mueller and Helsel, 1996; Fenelon and Moore, 1998; Barbash et al., 1999; and Nolan and Stoner, 2000; Gilliom et al., 2006; Stackelberg et al., 2006). The more clayey deposits and larger percentage of tile-drained cropland in the till, compared to the sand, probably either impede the downward movement of pesticides because of low permeability and/or sorption onto organic matter, or shunt the pesticides from tile drains to drainage ditches, rather than continuing to infiltrate to the water table. This process would result in lower concentrations of pesticides in the till than the sand.

\section{Selected Pesticides and Transformation Products in Ground Water From the Till}

Atrazine, metolachlor, acetochlor, and alachlor pesticides or their transformation products were detected in the till. Cyanazine, or its transformation product, cyanazine-amide, was not detected. Pesticides or their transformation products were detected in $35 \%$ (14 of 40) of the ground-water samples. Pesticides were detected in only 8\% (3 of 40) of the ground-water samples, whereas transformation products were detected in 35\% (14 of 40) of the ground-water samples. Pesticide, transformation product, and total concentrations are shown in Figure 4. Of the wells with detections, $50 \%$ (7 of 14) had two or more pesticide or transformation product detections. Individual pesticide detection frequencies, reporting levels, and estimated pesticide applications over the till are shown in Table 3.

Atrazine or its transformation products were detected in $10 \%$ (4 of 40 ) of the samples. In both samples 


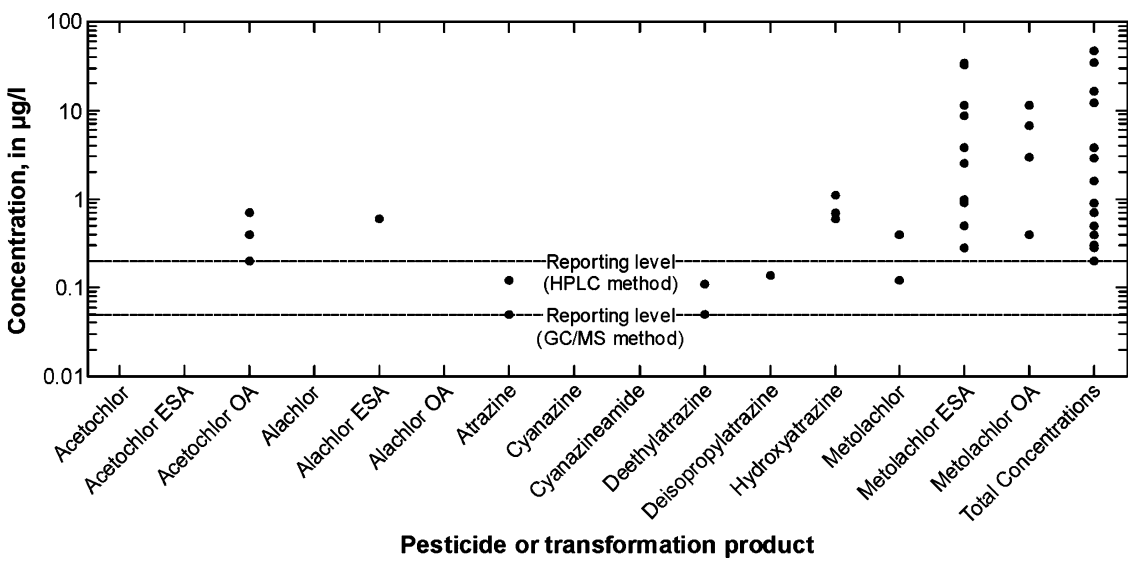

FIGURE 4. Pesticide, Transformation Product, and Total Concentrations From Ground-Water Samples in the Till.

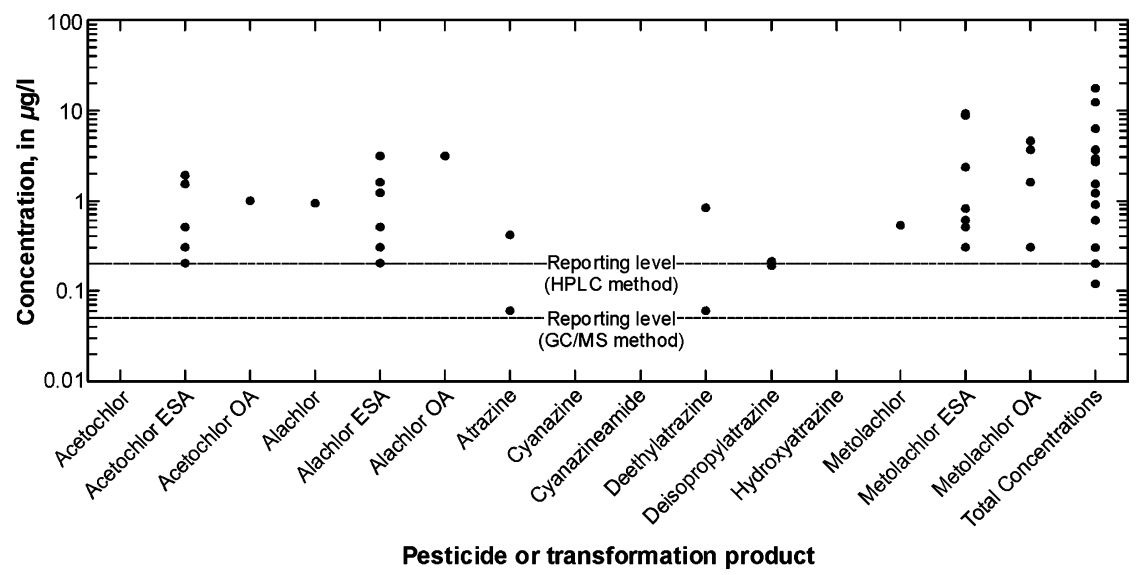

FIGURE 5. Pesticide, Transformation Product, and Total Concentrations From Ground-Water Samples in the Sand.

where atrazine was detected, two atrazine transformation products also were detected. These transformation products composed from 50 to $100 \%$ of the combined (atrazine and transformation products) concentration.

The most common transformation product of atrazine in ground water from the till is hydroxyatrazine, which was detected more frequently than atrazine. It is uncommon to find a higher concentration of hydroxyatrazine than atrazine or other transformation products, such as found in this study. Hydroxyatrazine is more soluble in water than atrazine, but solute-transport field experiments show that hydroxyatrazine has a substantially greater tendency to sorb to soils - particularly to the clay fraction (Barbash and Resek, 1996) and humic substances (Martin-Neto et al., 2001) than either atrazine, deethylatrazine, or deisopropylatrazine. Small amounts of dissolved organic carbon will act as a catalyst to increase the hydrolysis of atrazine, although the samples with the highest hydroxyatrazine concentrations had some of the lowest dissolved organic carbon concentrations.

Metolachlor or its transformation products were detected in $25 \%$ (10 of 40 ) of the samples. In both samples where metolachlor was detected, metolachlor ESA and metolachlor OA also were detected. Metolachlor ESA was the most frequently detected pesticide product in the till samples. Transformation products represent by far most of the total metolachlor product concentration in the till. Over $99 \%$ of the total metolachlor concentration is composed of the transformation products metolachlor ESA or metolachlor OA. Metolachlor ESA is the major metolachlor transformation product ( $82 \%$ of total ESA and OA). These results are similar to those from Iowa (Kalkhoff et al., 1998) and New York (Phillips et al., 1999). These studies found over $90 \%$ of the total metolachlor to be transformation products.

Acetochlor was not detected in ground water in Illinois or Iowa in 1994, the first year of extensive acetochlor use in the United States (Kolpin 
et al., 1996a). Acetochlor or acetochlor ESA also were not detected in samples collected from the till in 1997. However, acetochlor OA was detected in $8 \%$ (3 of 40) of the samples. This result differs from results in Iowa where acetochlor ESA was detected more frequently than OA (Kalkhoff et al., 1998), possibly because of differing soil properties and oxidizing conditions.

Alachlor or alachlor OA were not detected in samples from the till. Alachlor ESA was the only alachlor transformation product detected, with only $3 \%$ (1 of 40) of the samples having a detection. Alachlor application had decreased in Illinois and Indiana by an order of magnitude since the early $1990 \mathrm{~s}$, and application was an order of magnitude less than the other pesticide applications in the till in 1997. This result, combined with the possible shunting of pesticides into tile drains rather than having a longer residence time in the aquifer, may account for the low detections of alachlor products in ground water from the till.

\section{Ground-Water Ages in the Till}

Tritium samples were collected from 39 of 40 wells in the till. Tritium concentrations ranged from less than 1.8 to 21 TUs, with $80 \%$ (31 of 39) of the samples indicating recharge dates on or after 1952. Samples with pesticide detections ranged from less than 1.8 to 15 TUs. The two samples with tritium concentrations less than $1.8 \mathrm{TUs}$ (indicating recharge before 1952) also had detectable concentrations of acetochlor ESA. Acetochlor was not applied until after 1994. This result indicates that ground water in the till can be from mixed sources and ages, due in part to variations in ground-water flow in the fractured tills and intermittent sand lenses and/or mixing of water between the aquifer and aquitard material.

Dissolved oxygen and well depth also were examined as possible indicators of ground-water recharge age. Kolpin et al. (2000) used dissolved oxygen and depth to examine differences between older (dissolved oxygen concentration less than $0.50 \mathrm{mg} / \mathrm{l}$ and depth more than $15.2 \mathrm{~m}$ ) and younger ground water because oxygen tends to be consumed as water travels from land surface to greater depths. Well depth provides a general indication of distance from recharge. The median dissolved oxygen in the water samples from the till is $2.3 \mathrm{mg} / \mathrm{l}$ (range from 0.1 to $7.4 \mathrm{mg} / \mathrm{l}$ ) and the median depth of wells is $6.9 \mathrm{~m}$ (range from 4 to $17.9 \mathrm{~m}$ ) indicating recently recharged ground water. However, dissolved oxygen concentration and depth do not correlate with each other, or with total concentrations of pesticides in the till (Spearman Rank correlations all below -0.17). Therefore, well depth and dissolved oxygen only are a general indicator of age.
The results of pesticide detections in ground water and no detectable tritium and pesticide detections in samples with varying amounts of dissolved oxygen indicates that the determination of susceptibility of the till to contamination is not regionally consistent, but locally complex. Preferential transport through the heterogeneous till and discontinuous sand lenses by fractured till and macropores, and the occurrence and extent of tile drains are likely large factors for these detections of pesticides in "old" groundwater.

\section{Selected Pesticides and Transformation Products in Ground Water From the Sand}

Atrazine, metolachlor, acetochlor, and alachlor pesticides or their transformation products were detected in the sand. Cyanazine or cyanazine-amide were not detected. Pesticides and transformation products generally are present in the sand at higher concentrations and higher frequencies than in the till. Pesticides or their transformation products were detected in 55\% (16 of 29) of the ground-water samples. Pesticides were detected in only $10 \%$ (3 of 29 ) of the ground-water samples, whereas transformation products were detected in 55\% (16 of 29) of the ground-water samples. Pesticide, transformation product, and total concentrations are shown in Figure 5. Of the well samples with detections, $62 \%$ (10 of 16) had two or more pesticide or transformation product detections. Individual pesticide detection frequencies, reporting levels, and estimated pesticide applications over the sand are shown in Table 3.

Atrazine or its transformation products were detected in $14 \%$ (four of twenty-nine) of the samples. Of these samples, atrazine transformation products composed from $50 \%$ to $100 \%$ of the combined (atrazine and transformation products) concentration, except for one well sample. There were no detections of hydroxyatrazine, but all other atrazine transformation products were detected.

Metolachlor or its transformation products were detected in 38\% (11 of 29) of the samples. Transformation products represent by far most of the total metolachlor product concentration. As in the till and studies in Iowa and New York (Kalkhoff et al., 1998; Phillips et al., 1999), over 98\% of the total metolachlor product is composed of the transformation products metolachlor ESA or metolachlor OA in the sand. Metolachlor ESA also is the major metolachlor transformation product (70\% of total ESA and OA) and also is the most frequently detected pesticide in the sand. Metolachlor ESA was not as frequently codetected with metolachlor or metolachlor OA, as in the till, with only $10 \%$ of the samples having metolachlor 
ESA detections having concurrent detections of metolachlor products.

Acetochlor was not detected in samples from the sand, however, acetochlor ESA and acetochlor OA were both detected. Acetochlor ESA was the second most frequently detected pesticide product (along with alachlor ESA) in the sand samples, with a detection frequency of $24 \%$. This result is in agreement with acetochlor ESA having greater detection frequencies than acetochlor OA in Iowa (Kalkhoff et al., 1998).

Alachlor, alachlor ESA, and alachlor OA all were detected in samples from the sand. Alachlor application had decreased in Illinois and Indiana by an order of magnitude since the early 1990s, and application was nearly an order of magnitude less than other pesticide applications in the sand in 1997. However, alachlor ESA (along with acetochlor ESA) was the second most frequently detected pesticide product in the sand samples with a frequency of $24 \%$. This result differs from the detection frequencies in the till, indicating that ground water from the sand may have a longer residence time for pesticides because of the lack of tile drainage relative to the till. These higher concentrations of alachlor ESA relative to alachlor may relate to alachlor ESA (as well as metolachlor ESA) having higher water solubility and lower KOCs than their parent pesticides (Aga and Thurman, 2001).

\section{Ground-Water Ages in the Sand}

Chlorofluorocarbon samples were collected from 26 of 29 wells in the sand. Ground-water age dating using CFC concentrations is more precise than tritium, and the rural area and sandy, aerobic conditions of the ground water in sand are ideal for CFC sampling. Estimated recharge dates of ground water in the sand ranged from 1952 to 1999. Approximately 58\% (15 of 26) of the samples have apparent recharge dates from 1990 to 1999 (Figure 6).

Ground water recharged prior to 1990 is surprisingly more likely to have a detection of a pesticide or pesticide transformation product than ground water recharged on or after 1990 (Figure 7). Pesticides or transformation products were detected more than twice as frequently in ground-water samples recharged prior to 1990 [82\% (9 of 11)] than in ground-water samples recharged on or after 1990 [33\% (5 of 15)]. Total pesticide concentrations also were higher in the older ground water. The total pesticide median concentration of samples of ground water recharged on or after 1990 was $1.52 \mu \mathrm{g} / \mathrm{l}$, whereas the median concentration of samples of ground water before 1990 was less than the reporting levels of $0.05-0.20 \mu \mathrm{g} /$.
The highest concentrations of atrazine and transformation products, alachlor and transformation products, and metolachlor and transformation products also were detected in samples from ground water recharged prior to 1990 .

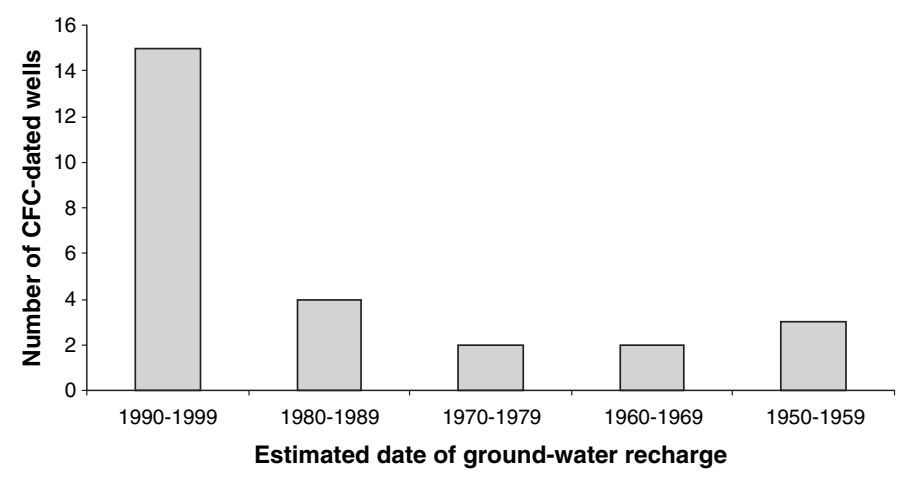

FIGURE 6. Estimated Dates of Ground-Water Recharge From Ground-Water Samples in the Sand Based on Chlorofluorocarbon (CFC) Analyses.

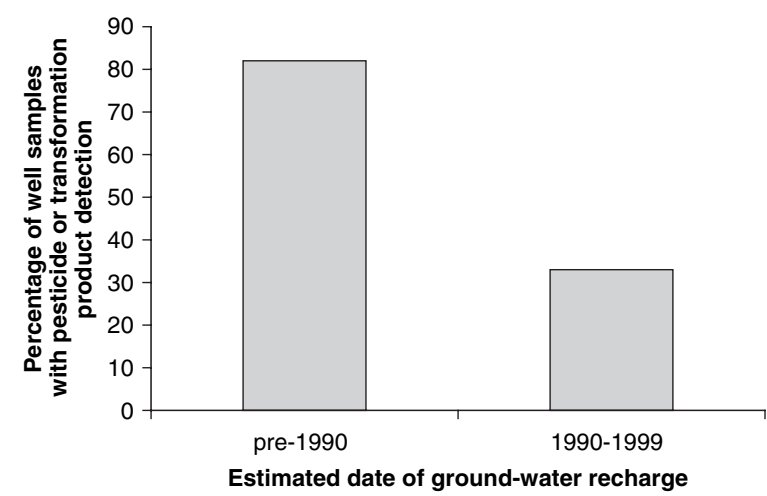

FIGURE 7. Percentage of Well Samples From Sand With a Pesticide or Transformation Product Detection and Estimated Date of Ground-Water Recharge.

It is probable that the ground-water recharge dates represent some mixing of different age waters. CFC ages are estimated ages derived from a piston-flow model. However, small amounts of ground water recharged on or after 1990 may have been transported through preferential pathways to mix with older (pre-1990) ground water, or intermixing of water between aquifers and aquitards may influence apparent ground-water age. Ground-water samples with older estimated ages actually may contain appreciable amounts of younger ground water (Bethke and Johnson, 2002; Weissmann et al., 2002). This preferential flow and/or mixing of younger and older ground water is indicated by samples with detections of acetochlor (first applied in 1994) transformation products with estimated recharge dates of 1964, 1968, 1984, and 1988. 
In the sand, the median dissolved oxygen concentration is $2.9 \mathrm{mg} / \mathrm{l}$, and the median well depth is $4.2 \mathrm{~m}$. These values indicate that ground water in the sand should be recently recharged. The median dissolved oxygen concentration is similar in ground water from the till ( $2.3 \mathrm{mg} \mathrm{mg} / \mathrm{l})$, but the median well depth $(6.9 \mathrm{~m})$ of the till is $64 \%$ deeper than the sand. In both the sand and till, depths and dissolved oxygen do not correlate and do not bear a relationship to ground-water age. Dissolved oxygen concentration and depth correlate poorly with total concentrations of pesticides in the sand (Spearman Rank correlations all below \pm 0.32 ), so are not good indicators of ground-water susceptibility in sand.

\section{SUMMARY AND CONCLUSIONS}

Pesticide and pesticide transformation product analyses were collected from samples in agricultural areas in Illinois and Indiana with similar pesticide applications from two shallow glacial deposits with differing permeabilities and geologic lithologies (till and sand), as well as different drainage and irrigation applications. Results indicated that ground water in low-permeability tills with a high clay content and also generally tile drained is less susceptible to pesticide contamination than ground water in the higher permeability sands that are generally not tile drained. There also is a statistical difference in total pesticide (original pesticide and transformation product) concentrations between samples from the sand and the till. In general, pesticides and transformation products are present in ground water from the till at lower concentrations and lower frequencies of detection than ground water from the sand.

Transformation products represent most of the agricultural pesticides found in ground water, regardless of type of deposit. In the till, transformation products were detected in $35 \%$ of the samples, whereas parent pesticides were only detected in $8 \%$ of the samples. In the sand, transformation products were detected in $55 \%$ of the samples, whereas parent pesticides only were detected in $10 \%$ of the samples. Hydroxyatrazine was detected more frequently than atrazine or other atrazine transformation products in the till, whereas hydroxyatrazine was not detected in the sand. The absence of hydroxyatrazine in the sand compared with the till probably is related to the sorbing characteristics of hydroxyatrazine with relation to clay, and combined with the much higher clay content of the till. Alachlor ESA detections also differed between the till and sand. Alachlor ESA was detected in $24 \%$ of the samples from the sand, but only was detected in $3 \%$ of the samples from the till. Pesticide persistence and mobility related to the difference in clay content and extent of tile drainage in the till and sand are the most probable causes for the difference in detection frequencies.

Higher frequencies of pesticide or pesticide transformation product detections are found in older ground water, as indicated by CFC age-dating. Contrary to expected results, ground water recharged before 1990 is more likely to have a detection of a pesticide or pesticide transformation product in the sand. Pesticides or transformation products were detected more than twice as frequently in ground water recharged prior to 1990 (82\% detection) than in ground water recharged on or after 1990 (33\% detection). The highest concentrations of atrazine and transformation products, alachlor and transformation products, and metolachlor and transformation products also were in samples from ground water recharged prior to 1990 . This disconnect between apparent ground-water age and pesticide detections may be affected by preferential flow and mixing of younger and older age ground water between aquifers and aquitards, indicated by samples with acetochlor transformation products detections (first applied in 1994) with estimated recharge dates before 1994, in the sand, and samples with acetochlor detections and estimated recharge dates before 1952 in the till. It is possible that these results also may be an indication that changes in pesticide management for cropland have helped reduce the presence of pesticides in ground water since 1990 over sand deposits, and possibly, till deposits.

\section{ACKNOWLEDGMENTS}

This research was funded by the U.S. Geological Survey, National Water-Quality Assessment program. Special acknowledgment is given for the technical help of George Groschen, U.S. Geological Survey and David Frothingham, U.S. Army Corps of Engineers.

\section{LITERATURE CITED}

Aga, D.S. and E.M. Thurman, 2001, Formation and Transport of the Sulfonic Acid Metabolites of Alachlor and Metolachlor in Soil. Environmental Science and Technology, 35: 2455-2460.

Arnold, T.L., D.L. Sullivan, M.A. Harris, F.A. Fitzpatrick, B.C. Scudder, P.M. Ruhl, D.W. Hanchar and J.S. Stewart, 1999. Environmental Setting of the Upper Illinois River Basin and Implications for Water Quality. U.S. Geological Survey WaterResources Investigations Report 98-4268, 67 pp. http://il.water.usgs.gov/nawqa/uirb/pubs/reports/WRIR_98-4268.pdf. Accessed March 2005.

Baker, D.B., L.K. Wallrabenstein and R.P. Richards, 1994. Well Vulnerability and Agrichemical Contamination-Assessments 
From a Voluntary Well Testing Program. In: New Directions in Pesticide Research, Development, Management, and Policy: Proceedings of the Fourth National Conference on Pesticides, D.L. Weigmann, (Editor). Virginia Polytechnic Institute and State University, Virginia Water Resources Center, Blacksburg, Virginia, pp.470-494.

Barbash, J.E. and E.A. Resek, 1996. Pesticides in Ground WaterDistribution, Trends, and Governing Factors. Ann Arbor Press, Chelsea, Michigan, 590 pp.

Barbash, J.E., G.P. Thelin, D.W. Kolpin and R.J. Gilliom, 1999. Distribution of Major Herbicides in Ground Water of the United States. U.S. Geological Survey Water Resources Investigations Report 98-4245, 57 pp. http://ca.water.usgs.gov/pnsp/rep/ wrir984245/. Accessed March 2005.

Bayless, E.R., 2001. Atrazine Retention and Degradation in the Vadose Zone at a Till Plain Site in Central Indiana. Ground Water 31:169-180.

Bethke, C.M. and T.M. Johnson, 2002. Paradox of Groundwater Age. Geology 30:385-388. http://www.geology.uiuc.edu/ bethke/ pdf/Geology2002.pdf. Accessed March 2005.

Bouwer, H. and R.C. Rice, 1976. A Slug Test for Determining Hydraulic Conductivity of Unconfined Aquifers With Completely or Partially Penetrating Wells. Water Resources Research 12:423-428.

Cooper, H.H., J.D. Bredehoeft and I.S. Papadopulos, 1967. Response of a Finite-Diameter Well to an Instantaneous Change of Water. Water Resources Research 3:263-269.

Fenelon, J.M. and R.C. Moore, 1998. Transport of Agrichemicals to Ground and Surface Water in a Small Central Indiana Watershed. Journal of Environmental Quality 27:884-894.

Gianessi, L.P. and M.B. Marcelli, 2000. Pesticide Use in U.S. Crop Production: 1997 National Summary Report. National Center for Food and Agricultural Policy. Washington, D.C., 101 pp. http://www.ncfap.org/ncfap/nationalsummary1997.pdf. Accessed March 2005.

Gilliom, R.J., J.E. Barbash, C.G. Crawford, P.A. Hamilton, J.D. Martin, N. Nakagaki, L.H. Nowell, J.C. Scott, P.E. Stackelberg, G.P. Thelin and D.M. Wolock, 2006. The Quality of Our Nation's Waters-Pesticides in the Nation's Streams and Ground Water 1992-2001: U.S. Geological Survey Circular 1291, 172 pp. http:// pubs.usgs.gov/circ/2005/1291/pdf/circ1291.pdf. Accessed February 2007.

Helsel, D.R. and R.M. Hirsch, 1992. Statistical Methods in Water Resources. Elsevier Science Publishers, New York, New York.

Kalkhoff, S.J., D.W. Kolpin, E.M. Thurman, I. Ferrer and D. Barcelo, 1998. Degradation of Chloroacetanilide Herbicides: The Prevalence of Sulfonic and Oxanilic Acid Metabolites in Iowa Groundwaters and Surface Waters. Environmental Science and Technology 32:1738-1740.

Kish, J.L., E.M. Thurman, E.A. Scribner and L.R. Zimmerman, 2000. Methods of Analysis by the U.S. Geological Survey Organic Geochemistry Research Group-Determination of Selected Herbicides and Their Degradation Products in Water Using Solid-Phase Extraction and Gas Chromatography/Mass Spectrometry. U.S. Geological Survey Open-File Report 00-385, 13 pp. http://ks.water.usgs.gov/Kansas/pubs/reports/ofr.00-385.html. Accessed March 2005.

Kolpin, D.W., M.R. Burkhart and E.M. Thurman, 1994. Herbicides and Nitrate in Near-Surface Aquifers in the Midcontinental United States, 1991. U.S. Geological Survey Water-Supply Paper 2413, 34 pp.

Kolpin, D.W., B.K. Nations, D.A. Goolsby and E.M. Thurman, 1996a. Acetochlor in the Hydrologic System in the Midwestern United States, 1994. Environmental Science and Technology 30:1459-1464.

Kolpin, D.W., E.M. Thurman and D.A. Goolsby, 1996b. Occurrence of Selected Pesticides and Their Metabolites in Near-Surface
Aquifers of the Midwestern United States. Environmental Science and Technology 30:335-340.

Kolpin, D.W., E.M. Thurman and S.M. Linhart, 1998. The Environmental Occurrence of Herbicides-The Importance of Degradates in Ground Water. Archives of Environmental Contamination and Toxicology 35:385-390.

Kolpin, D.W., E.M. Thurman and S.M. Linhart, 2000. Finding Minimal Herbicide Concentrations in Ground Water? Try Looking for Their Transformation Products. The Science of the Total Environment 248:115-122.

Koterba, M.T., F.D. Wilde and W.W. Lapham, 1995. Ground-Water Data-Collection Protocols and Procedures for the National Water-Quality Assessment Program: Collection and Documentation of Water-Quality Samples and Related Data. U.S. Geological Survey Open-File Report 95-399, 113 pp. http://water. usgs.gov/nawqa/ofr95-399/ofr95-399book.pdf. Accessed March 2005.

Lapham, W.W., F.D. Wilde and M.T. Koterba, 1995. Ground-Water Data-Collection Protocols and Procedures for the National Water-Quality Assessment Program: Selection, Installation, and Documentation of Wells, and Collection of Related Data. U.S. Geological Survey Open-File Report 95-398, 70 pp. http://water. usgs.gov/nawqa/ofr95-398/ofr95-398book.pdf. Accessed March 2005.

Martin-Neto, L., D.G. Traghetta, C.M.P. Vaz, S. Crestana and G. Sposito, 2001. On the Interaction Mechanisms of Atrazine and Hydroxyatrazine With Humic Substances. Journal of Environmental Quality 30:520-525.

Monsanto Company, 2003. Material Safety Data Sheet: Herbicide Degree Xtra, 11 pp. http://scgw1.monsanto.com/esh/msdslib.nsf/ 885008FABCB67DF60625680E0072A759/\$file/DegreeXtra.303.pdf. Accessed October, 2005.

Morrow, W.S., 2003. Anthropogenic Constituents in Shallow Ground Water in the Upper Illinois River Basin. U.S. Geological Survey Water-Resources Investigations Report 02-4293, 29 pp. Available at http://il.water.usgs.gov/pubs/wrir02_4293.pdf. Accessed in March 2005.

Mueller, D.K. and D.R. Helsel, 1996. Nutrients in the Nation's Waters-Too Much of a Good Thing?. Circular 1136, 24 pp.

Mueller, D.K., P.A. Hamilton, D.R. Helsel, K.J. Hitt and B.C. Ruddy, 1995. Nutrients in Ground Water and Surface Water of the United States-An Analysis of Data Through 1992. U.S. Geological Survey Water-Resources Investigations Report 954031, 74 pp.

Nolan, B.T. and J.D. Stoner, 2000. Nutrients in Ground Waters of the Conterminous United States, 1992-1995. Environmental Science and Technology 34:1156-1165.

Phillips, P.J., G.R. Wall, E.M. Thurman, D.A. Eckhardt and J. Van Hoesen, 1999. Metolachlor and Its Metabolites in Tile Drain and Stream Runoff in the Canajoharie Creek Watershed. Environmental Science and Technology 33:3531-3537.

Plummer, L.N. and E. Busenberg, 1999. Chlorofluorocarbons. In: Environmental Tracers in Subsurface Hydrology, P. Cook and A. Herczeg (Editors). Kluwer Academic Press, Boston, Massachusetts, pp. 441-478.

Plummer, L. and L. Friedman, 1999. Tracing and Dating Young Ground Water: U.S. Geological Survey Fact Sheet 134-99, 4 pp. http://water.usgs.gov/pubs/FS/FS-134-99/pdf/fs-134-99.pdf. Accessed March 2005.

Ray, C. and S.C. Schock, 1996. Comparability of Large-Scale Studies of Agricultural Chemical Contamination of Rural Private Wells. Ground Water Monitoring and Remediation 17:92-102.

Richards, R.P., D.B. Baker, B.R. Christenson and D.P. Tierney, 1995. Atrazine Exposures Through Drinking Water-Exposure Assessments for Ohio, Illinois, and Iowa. Environmental Science and Technology 29:406-412. 
Risch, M.R, 1993. A Summary of Pesticides in Ground-Water Data Collected by Government Agencies in Indiana, December 1985 to April 1991. U.S. Geological Survey Open-File Report 93-133, $30 \mathrm{pp}$.

Savoca, M.E., E.M. Sadorf, S.M. Linhart and K.K.B. Akers, 2000. Effects of Land Use and Hydrogeology on the Water Quality of Alluvial Aquifers in Eastern Iowa and Southern Minnesota, 1997. U.S. Geological Survey Water-Resources Investigations Report 99-4246, 38 pp. http://ia.water.usgs.gov/nawqa/reports/ WRIR.99-4246.pdf. Accessed March 2005.

Scott, J.C., 1990. Computerized Stratified Random Site-Selection Approaches for Design of a Ground-Water-Quality Sampling Network. U.S. Geological Survey Water-Resources Investigations Report 90-4101, 109 pp.

Stackelberg, P.E., R.J. Gilliom, D.M. Wolock and K.J. Hitt, 2006. Development and Application of a Regression Equation for Estimating the Occurrence of Atrazine in Shallow Ground Water Beneath Agricultural Areas of the United States: U.S. Geological Survey Scientific Investigations Report 2005-5287, 12 pp. http://pubs.usgs.gov/sir/2005/5287/ Accessed February 2007.

Thatcher, L.L., V.J. Janzer and K.W. Edwards, 1977. Methods for the Determination of Radioactive Substances in Water and Fluvial Sediments. U.S. Geological Survey Techniques of WaterResources Investigations, book 5, chap. A5, 95 pp. http://water.usgs.gov/pubs/twri/twri5a5/pdf/TWRI_5-A5.pdf. Accessed March 2005.

Toccalino, P.L., J.E. Norman, R.H. Phillips, L.J. Kauffman, P.E. Stackelberg, N.H. Nowell, S.J. Krietzman and G.B. Post, 2004. Application of Health-Based Screening Levels to Ground-Water Quality Data in a State-Scale Pilot Effort: U.S. Geological Survey Scientific Investigations Report 2004-5174, 64 pp. http:// pubs.usgs.gov/sir/2004/5174/sir20045174.pdf Accessed February 2007.

U.S. Department of Agriculture, 1997. Agricultural Chemical Usage (PCU-BB). USDA National Agricultural Statistics Service. http://usda.mannlib.cornell.edu/reports/nassr/other/pcu-bb/. Accessed March 2005.

U.S. Department of Agriculture, 1999. 1997 Census of Agriculture: Geographic Area Series, Volume 1, 1A, 1B, 1C. USDA National Agricultural Statistics Service. http://govinfo.kerr.orst.edu/agstateis.html. Accessed March 2005.

U.S. Environmental Protection Agency, 1998. Announcement of the Drinking Water Contaminant List. Federal Register, v. 63, no. 40, P. 10273-10287. http://www.epa.gov/fedrgstr/EPA-WATER/ 1998/March/Day-02/w5313.htm. Accessed March 2005.

U.S. Environmental Protection Agency, 2005. The Drinking Water Contaminant Candidate List-the Source of Priority Contaminants for the Drinking Water Program: U.S. Environmental Protection Agency Fact Sheet, Office of Water, EPA 815-F-05001, February 2005, 6 pp. Available at http://www.epa.gov/safewater/ccl/pdfs/fs_ccl2_final-02-23-05.pdf. Accessed February 2007.

Wagenet, L.P., A.T. Lemley and R.J. Wagenet, 2000. A Review of Physical-Chemical Parameters Related to Soil and Groundwater Fate of Selected Pesticides in New York State. Cornell University, Ithaca, New York. Available at http://pmep.cce.cornell.edu/ facts-slides-self/facts/pchemparams/index.html. Accessed March 2005.

Warner, K.L., 1998. Water-Quality Assessment of the Lower Illinois River Basin: Environmental Setting. U.S. Geological Survey Water-Resources Investigations Report 97-4165, 50 pp. http://il.water.usgs.gov/proj/lirb/pubs/pdfs/envset.pdf. Accessed March 2005.

Wauchope, R.D., T.M. Buttler, A.G. Hornsby, P.W.M. AugustijnBeckers and J.P. Burt, 1992. SCS/ARS/CES Pesticides Properties Database for Environmental Decision Making. Reviews of Environmental Contamination and Toxicology. 123:1-157, 1992.2-26.
Weissmann, G.S., Y. Zhang, E.M. LaBolle and G.E. Fogg, 2002. Dispersion of Groundwater Age in an Alluvial Aquifer System. Water Resources Research 38(10):16. http://www.msu.edu/ weissman/pubs/2001WR000907.pdf. Accessed March 2005.

Willman, H.B., E. Atherton, T.C. Buschbach, Collinson, Charles, J.C. Frye, M.E. Hopkins, J.A. Lineback and J.A. Simon, 1975, Handbook of Illinois Stratigraphy: Illinois State Geological Survey Bulletin 95, $261 \mathrm{pp}$.

Zimmerman, L.R. and E.M. Thurman, 1999. Method of Analysis by the U.S. Geological Survey Organic Geochemistry Research Group-Determination of Triazine and Chloroacetanilide Herbicides in Water by Solid-Phase Extraction and Capillary-Column Gas Chromatography/Mass Spectrometry With Selected-Ion Monitoring. U.S. Geological Survey Open-File Report 98-634, 21 pp.

Zimmerman, L.R., K.A. Hostetler and E.M. Thurman, 2000. Methods of Analysis by the U.S. Geological Survey Organic Geochemistry Research Group-Determination of Chloroacetanilide Herbicide Metabolites in Water Using High-Performance Liquid Chromatography-Diode Array Detection and High-Performance Liquid Chromatography/Mass Spectrometry. U.S. Geological Survey Open-File Report 00-182, 30 pp. http://ks.water.usgs.gov/ Kansas/pubs/reports/ofr.00-182.html. Accessed March 2005. 